\title{
Studi Nilai Etnobotani dan Sosio-Ekologi Generasi Milenial Sumba Yang
} Studi Lanjut Di Luar Daerah Asal

\author{
Yuswa Istikomayanti $1^{*}$, Zuni Mitasari ${ }^{2}$ \\ 1,2Pendidikan Biologi, Fakultas Ilmu Pendidikan, Universitas Tribhuwana Tunggadewi, Indonesia
}

\begin{abstract}
ABSTRAK
Etnis dan lingkungan alam hidup berdampingan. Namun, dengan seiring berkembangnya modernisasi hingga ke berbagai pelosok daerah juga menjadikan tantangan untuk masyarakat adat tetap bertahan di masa depan. Tujuan penelitian ini untuk mendeskripsikan nilai-nilai etnobotani pada generasi milenial Sumba serta mengkaji aspek sosio-ekologi sebagai perspektif baru dalam kajian etnobotani. Milenial Sumba yaitu mahasiswa Universitas Tribhuwana Tunggadewi yang merupakan anak daerah yang masih hidup dengan lingkungan kebudayaan khususnya daerah Sumba, Nusa Tenggara Timur. Melalui kuesioner, pertanyaan terbuka serta wawancara mendalam pada responden kunci dapat dikaji sejauh mana nilai-nilai kebudayaan yang ada pada generasi milenial Sumba yang telah mengenyam pendidikan dan kehidupan modern di Kota Malang, Jawa Timur, Indonesia. Kajian sosio-ekologi menjadi penting untuk dilakukan sebagai perspektif dalam pengambilan arah berbagai kebijakan. Khususnya dalam arah pendidikan, pemilihan, dan penentuan nilai-nilai adat dan bagaimana upaya pelestariannya menjadi etnis dan lingkungan yang saling berdampingan. Hasil yang diperoleh sebagian besar $(48 \%)$ generasi milenial masih memegang nilai adat dalam perilakunya sehari-hari. Aspek tersebut tercermin dalam penggunaan obat tradisional akar kayu/Linno, Psidium guajava, Annona muricata, Zingiber officinale, Curcuma zedoaria, Swietenia mahagoni, Piper betle, Cocos nucifera, Persea americana, Chromolaena odorata, Muntingia calabura, Ocimum basilicum, Coffea Sp., Anredera cordifolia, Phaleria macrocarpa. Keterampilan menenun, mewarnai secara alami, makan sirih-pinang, serta persepsi positif (48\%) terhadap kelestarian budayanya di masa depan.
\end{abstract}

Kata kunci: etnobotani, Indonesia, milenial, Sumba, Sosio-Ekologi

\begin{abstract}
Ethnic and natural environments coexist together. However, along with the development of modernization to various corners of the region also makes challenges for indigenous peoples to remain in the future. The purpose of this study is to describe ethnobotany values in the Sumba millennial generation and to examine the socio-ecological aspects as a new perspective in ethnobotany studies. Sumba millennials are students of the Tribhuwana Tunggadewi University who are regional children who still live with a cultural environment, especially the Sumba area, East Nusa Tenggara. Through questionnaires, open questions and in-depth interviews with key respondents, it can be assessed the extent to which cultural values exist in the Sumba millennial generation who have received education and modern life. Socio-ecological studies are important to be carried out as a perspective in making various policy directions. Particularly in the direction of education, selection, and determination of customary values and how efforts to conserve them become co-existent ethnicities and environments. The results obtained by most of the millennial generation still hold customary values in their daily behavior (48\%). This aspect is reflected in the use of traditional medicine, akar kayu/Linno, Psidium guajava, Annona muricata, Zingiber officinale, Curcuma zedoaria, Swietenia mahagoni, Piper betle, Cocos nucifera, Persea americana, Chromolaena odorata, Muntingia calabura, Ocimum basilicum, Coffea Sp., Anredera cordifolia, Phaleria macrocarpa. Skills in weaving, natural coloring, eating betel-nut, and positive perceptions (48\%) of the preservation of its culture in the future.
\end{abstract}

Keywords:Ethnobotany, Indonesia, Milenial, Sumba, Socio-Ecology

*) Yuswa Istikomayanti, Universitas Tribhuwana Tunggadewi, Pendidikan Biologi, Jl. Telaga Warna Tlogomas, Telp./handphone: 0341565500 and e-mail:yuswa2710@gmail.com

doi: 10.33474/e-jbst.v7i1.394

Diterima tanggal 4 Februari 2021-Diterbitkan Tanggal 31 Agustus 2021

http://creativecommons.org/licenses/by/4.0 


\section{Pendahuluan}

Studi nilai etnobotani memiliki kepentingan tidak hanya praktik penggunaan tanaman obat dalam kehidupan sehari-hari atau farmaka-etnobotani. Dalam kajian ini akan digali bagaimana nilainilai praktik etnobotani dalam aspek lainnya seperti keterampilan menenun, keterampilan mewarnai, penggunaan tanaman obat di luar daerah asal, serta nilai penghargaan budaya oleh generasi penerus yaitu generasi milenial. Dalam dunia modern saat ini, daerah terluar dari batas Tenggara Indonesia yaitu pulau Sumba, Nusa Tenggara Timur. Keindahan pulau Sumba dari sisi bentang alam dan kebudayaannya banyak memikat peneliti dari luar negeri sejak puluhan tahun yang lalu. Bahkan Bapak Seniman Indonesia, Taufiq Ismail menggambarkan keindahan Sumba dalam puisi "Beri Daku Sumba" digambarkan dengan kuda-kudanya, dengan laut dan pantainya yang indah. Selain itu Sumba adalah salah satu daerah adat yang masih memiliki kekayaan leluhur dan lestari hingga saat ini.

Pulau Sumba terletak di bagian tenggara Negara Kesatuan Republik Indonesia, terbagi menjadi 4 (empat) kabupaten dengan populasi penduduk sebesar 781.093 jiwa. Keempat kabupaten tersebut merupakan pusat kantor pemerintahan, sekolah, pusat perdagangan/pasar, dan pusat pelayanan. Meskipun kita mengenal Sumba sebagai daerah terisolasi, namun saat ini Pulau Sumba telah memiliki dua bandara udara yang beroperasi sehari-hari menuju Pulau Bali dan Kupang. Mata pencaharian penduduk Sumba sebagian besar dalam bidang pertanian untuk mencukupi kebutuhan sehari-hari. Iklimnya bervariasi dan cenderung kering dengan bentangan padang savana yang luas. Bagian utara dan timur Sumba merupakan daerah yang tidak ditanami pertanian dan saat ini menjadi daerah investasi asing untuk perkebunan dan juga sebagian pantai di Sumba telah dijual kepada investor untuk menjadi "The Next Bali” (1).

Penduduk Sumba adalah penduduk asli yang secara turun temurun telah menempati suatu wilayah adat yang mereka klaim. Beberapa wilayah merupakan daerah teritorial sub-suku adat yang menempatinya secara turun temurun. Suku Sumba sampai saat ini masih mempercayai Marapu yaitu kepercayaan dari nenek moyang mereka. Marapu merupakan cara hidup yang mengatur bagaimana menggunakan tanah, air, hutan, dan bagian dari alam. Mengikuti aturan dan norma dari leluhurnya adalah kepercayaan orang Магари yang mana jika melanggar maka kehidupan mereka dan takdir mereka akan terpengaruh, menyebabkan penyakit, dan bahkan kerusakan (1).

Pada organisasi sosial terdiri dari beberapa klan atau Kabihu dan menganut garis keturunan ayah atau patrilinenal. Seorang wanita yang telah menikah maka akan pindah ke rumah suaminya dan suami memberikan seserahan berupa hewan ternak seperti kerbau, kuda, dan barang berharga seperti emas. Sedangkan keluarga suami akan mendapatkan balasan yaitu hewan ternak babi, dan kain "Tenun Ikat". Seorang wanita yang telah menikah tidak mewarisi tanah warisan dari orang tuanya, dan menjadi anggota baru dalam klan keluarga suaminya. Pembagian kasta sosial juga ada yaitu terbagi menjadi kaum bangsawan, orang bebas, dan budak. Selain itu pada kaum bangsawan juga memiliki pemimpin adat yaitu disebut maramba. Organisasi sosial ini membawa beberapa dinamika sosial yaitu adanya permasalahan akusisi tanah adat oleh suku adat dan pemerintah serta investor asing (1).

Kebudayaan suku Sumba telah dituliskan sejak abad ke-15 yaitu pada kitab Negarakertagama pada kerajaan Majapahit. Kebudayaan yang ada sampai saat ini merupakan peninggalan kebudayaan zaman megalitikum dan masih lestari hingga saat ini. Situs patung pertama yang ada yaitu di daerah Wainyapu, Kodi yaitu batu tunggal yang telah berdiri sejak 500 tahun yang lalu (2). Kajian kebudayaan dan lingkungan menjadi suatu pendekatan yang banyak dilakukan. Kajian sosio-ekologi adalah kajian dari sisi manusia sebagai pusat peradaban yang mampu mengendalikan dan mengarahkan kemana lingkungan tersebut berkembang. Sedangkan dalam pendekatan biosentris maka alam adalah sebagai pusat kehidupan yang mengendalikan kehidupan manusia.

Pendekatan sosio-ekologi dinilai dapat menjadi perspektif baru dalam kajian etnobotani yang terjadi dari kondisi saat ini seperti penelitian lainnya, yaitu Muhammad Obie melakukan kajian sosioekologi yang terjadi pada konflik antar etnis dan juga pemerintah, dimunculkan karena pemerintah memberikan kewenangan pengelolaan SDA kepada pihak asing (3), Anthony Charles mengkaji perubahan iklim dan sistem sosio-ekologi melalui analisis hubungan manusia, laut dan lingkungan 


\section{e-Jurnal Ilmiah BIOSAINTROPIS (BIOSCIENCE-TROPIC) Volume : 7/ No : 1 / Halaman 63 - 73 / Agustus Tahun 2021 ISSN : 2460-9455 (e) - 2338-2805(p)}

(4), dan penggunaan tanaman obat oleh Suku Sumba merupakan salah satu bentuk interaksi sosioekologi yang masih terjaga (5). Melalui kajian sosio-ekologi diharapkan mampu memberikan perspektif baru berbagai pihak untuk menentukan keputusan dan arah orientasi masa depan. Studi sosio-ekologi oleh peneliti menyatakan bahwa melalui penghargaan nilai-nilai pada aspek sosioekologi maka mampu meningkatkan penilaian masyarakat terhadap praktik-praktik kebudayaan dan kearifan lokal yang telah dilakukan (6).

Menurut studi psikologi manusia, kognitif perilaku manusia seperti piramida terbalik seperti pada Gambar 1. Nilai atau value adalah keyakinan yang berkaitan dengan keadaan akhir yang diinginkan atau mode perilaku melampaui situasi tertentu, kemampuan memilih, dan mengevaluasi perilaku, orang, dan peristiwa, dan diurutkan berdasarkan kepentingan relatif ke nilai lain untuk membentuk sistem prioritas nilai. Nilai dalam masyarakat dapat berupa agama, kepercayaan, kebudayaan, serta paham baru. Nilai ini sulit untuk berubah, mampu melampaui batas ruang waktu, dan perubahannya hanya sedikit. Pembentukan nilai dalam manusia terbentuk sejak masa kanakkanak, terjadi interaksi nilai dalam proses sosialisasi, dan akan membentuk kestabilan pada masa dewasa.

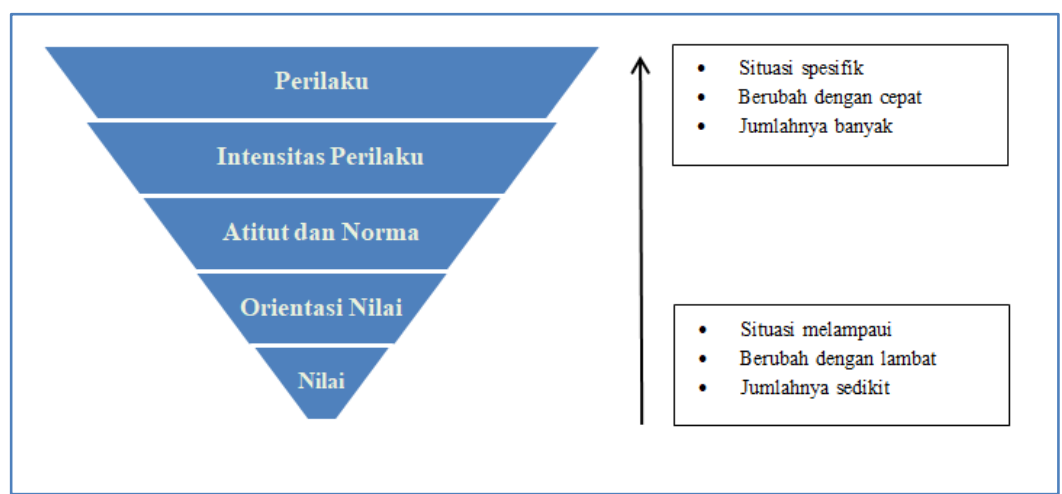

Gambar 1. Model Hierarki Kognitif Perilaku Manusia (Fulton et al., 1996 dalam Jones et al., 2016)

Pada Gambar 1. menunjukkan bahwa tujuan konservasi berkelanjutan tidak terjadi secara instan dan akan diperoleh dalam waktu sesaat (6). Perlu waktu yang lama untuk membentuk nilai pada masyarakat dan lingkungan sosial. Namun, sampai saat ini dunia modern masih mengalami masalah ancaman lingkungan akibat industrialisasi, modernisasi dan konsumerisme. Hal ini sangat disayangkan jika kita sebagai bangsa Indonesia yang berbudaya belum menyadari pentingnya kebudayaan nenek moyang untuk lebih digali kearifan dan keunggulannya.

Kajian sosio-ekologis merupakan kajian lintas bidang yang saling berhubungan dapat dipetakan menjadi aspek estetika, ekologi, humanistik, moralistik, naturalistik, spiritual, simbol dan lain-lain (7). Melalui kajian ini juga semakin meningkat pada beberapa penelitian seperti penelitian pada masyarakat Dayak (8), penelitian mengembangkan ekowisata dari tradisi berbasis etnobotani, (9) serta pada bidang lain seperti kajian etnomatematika pada kain tenun. Melalui studi kasus pada generasi milenial Sumba kita mampu mengkaji bagaimana tindakan sebagai praktisi, masyarakat umum dan yang lainnya (10).

Hasil penelitian menyatakan telah terjadi proses pembentukan identitas baru di masyarakat Sumba (11). Dualisme yaitu tetap menjadi penganut kepercayaan Marapu dan sebagian menganut agama Kristen Sumba. Implikasinya, proses pembentukan identitas baru terjadi pada generasi selanjutnya. Dengan demikian, semakin majunya suatu daerah dengan modernisasi di Indonesia maka dapat diprediksi, nilai-nilai kebudayaan yang ada justru semakin meluntur. Bagaimana hal ini akan terus berlanjut dengan semakin banyaknya remaja yang berpendidikan serta berkurangnya kaum tetua adat yang tidak memiliki penerus kebudayaan. Tentunya hal ini dapat berdampak pada segala aspek lingkungan, ekonomi, sosial, dan budaya. 
Kajian penggunaan obat tradisional di masyarakat Sumba banyak dilakukan oleh peneliti, yaitu tentang sumber daya hayati flora pada masyarakat Sumba yang bernilai religius, seperti penggunaan beberapa spesies sebagai atribut simbolik religius, seperti sirih (Piper betle L.) dan buah pinang (Arecha cathecu L.) dalam setiap upacara adat, terutama oleh penganut Marapu sebagai sebuah aliran kepercayaan terhadap roh leluhur. Penerapan atribut simbolik dalam skala luas diwujudkan berupa sejumlah situs-situs religius berbasis sumberdaya alam, diantaranya hutan marapu, kampung marapu dan tanah biha/paita (tanah suci atau tanah larangan) yang dimanfaatkan secara terbatas atau bahkan terlarang (11). Kajian tanaman obat di Sumba Barat Daya terdapat 17 spesies tanaman yang paling banyak digunakan sebagai tanaman obat oleh masyarakat Sumba Barat Daya. Hasil penelitian menyatakan masyarakat Sumba memiliki usaha yang besar dalam melestarikan tanaman obat baik dalam memelihara, menggunakan dan menekuni yaitu dengan adanya ahli tanaman obat/ dukun di daerah tersebut (12).

Tujuan penelitian ini yaitu mendeskripsikan nilai-nilai etnobotani pada generasi milenial Sumba serta mengkaji aspek sosio-ekologi sebagai perspektif baru dalam kajian etnobotani. Kajian ini sebagai upaya memberikan gambaran kepada masyarakat luas, pemegang kepentingan, dan masyarakat adat Sumba khususnya generasi penerus untuk merefleksikan kembali kebudayaan yang dimiliki, apakah secara dinamis mampu mempertahankan nilai-nilai yang ada. Melalui kajian perilaku penggunaan tanaman oleh generasi milenia Sumba, maka akan diperoleh sejauh mana nilai-nilai yang masih mereka pegang dalam upaya pelestarian budaya dan juga pelestarian alam.

\section{Material dan Metode}

Penelitian ini dilaksanakan pada bulan September - Desember 2020, dengan melakukan analisis pendahuluan, kajian literatur, serta memberikan kuesioner secara online melalui google form, dan melakukan wawancara mendalam secara virtual melalui telepon. Kuesioner diberikan kepada 55 responden melalui purposive sampling yaitu menggali informasi pada responden yang memiliki latar belakang kehidupan budaya Sumba, serta merupakan mahasiswa aktif di Universitas Tribhuwana Tunggadewi (UNITRI), Kota Malang. Mahasiswa UNITRI sebesar 70\% lebih berasal dari daerah Sumba, Nusa Tenggara Timur (NTT). Responden kunci yang diwawancarai adalah anak adat yang berasal dari keluarga yang memegang kebudayaan, namun juga mengalami pendidikan modern.

Pertanyaan yang diberikan meliputi aspek pengetahuan responden terhadap preferensi makanan khas daerah, penggunaan obat tradisional, keterampilan menenun, mewarnai benang secara alami, pengetahuan keberagaman corak kain tenun ikat, dan pendapat generasi milenial Sumba terhadap masa depan kebudayaanya. Analisis sosio-ekologi dikaji melalui perbandingan hasil penelitian dengan kajian literatur yaitu hasil penelitian sebelumnya sebagai data sekunder untuk mendeskripsikan poin-poin utama yang perlu dikembangkan dari hasil penelitian ini.

\section{Metode}

Pertanyaan dari kuesioner berjumlah 25 pertanyaan baik pertanyaan pilihan dan juga pertanyaan terbuka. Pertanyaan dikirimkan secara online melalui google form kepada mahasiswa, dengan mengisi identitas nama, asal daerah, lama waktu tinggal di Kota Malang, dan asal daerah. Metode selanjutnya yaitu menyeleksi hasil kuesioner untuk melihat responden kunci serta melakukan pertimbangan lainnya. Responden kunci diberikan beberapa pertanyaan terbuka dan diwawancarai mendalam untuk menggali informasi, hasil wawancara didokumentasikan dengan catatan lapang. Data yang diperoleh dianalisis secara kualitatif dan kuantitatif. Data primer disajikan dalam bentuk diagram serta dikaji dengan mencari penguatan pada deskripsi jawaban terbuka dan wawancara mendalam. Data disajikan secara naratif, implikatif dalam lingkup pendekatan sosio-ekologi. 


\section{Hasil dan Diskusi}

\section{Potensi dan Kelemahan Generasi Milenial Sumba}

Hasil kuesioner yang diberikan kepada generasi milenial Sumba pada aspek mengkonsumsi jamu atau obat tradisional tersaji pada Gambar 2. Beberapa tanaman yang digunakan sebagai obatobatan dari data pertanyaan terbuka yaitu untuk sakit pencernaan seperti maag dan diare menggunakan akar kayu/Linno, daun Jambu Biji (Psidium guajava), obat batuk/ sakit tenggorokan menggunakan rebusan daun sirsak (Annona muricata), jahe (Zingiber officinale), dan kunyit putih (Curcuma zedoaria). Obat sakit kepala dan demam menggunakan daun dan akar mahoni (Swietenia mahagoni), air rebusan untuk mandi, rebusan sirih (Piper betle), dan minyak kelapa (Cocos nucifera)

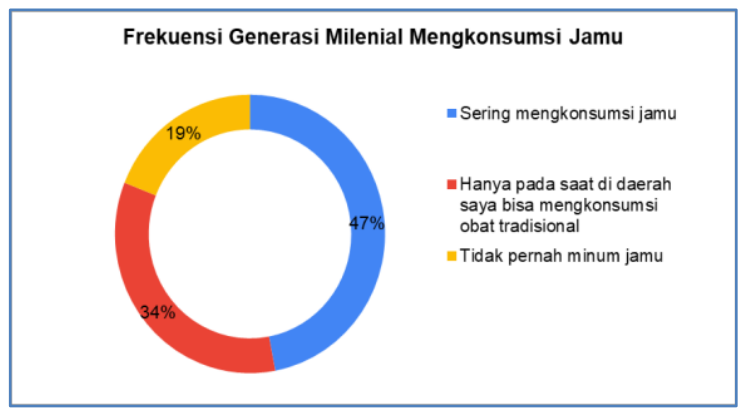

Gambar 2. Frekuensi Mengkonsumsi Jamu oleh Generasi Milenial Sumba

jika sakit, serta Alpukat (Persea americana) untuk sakit kandung kemih. Daun balakacida/babdotan (Chromolaena odorata) direbus untuk luka, buah karsen (Muntingia calabura) untuk sakit maag, akar kemangi (Ocimum basilicum) air rebusan untuk sakit gigi, daun kopi (Coffea sp.) air rebusan untuk sakit perut, daun binahong (Anredera cordifolia) untuk penyakit dalam, dan buah mahkota dewa (Phaleria macrocarpa) untuk sesak nafas. Sebesar 47\% remaja milenial yaitu mahasiswa asal Sumba masih menemukan tanaman obat di sekitar mereka untuk dikonsumsi jika merasakan sakit ringan. Sedangkan sebesar 34\% tidak terampil meracik obat tradisional tetapi masih mengkonsumsi jika mereka pulang kampung, dan hanya 19\% mahasiswa asal Sumba yang sudah tidak mengkonsumsi obat tradisional untuk mengurangi dan mengobati sakit ringan.

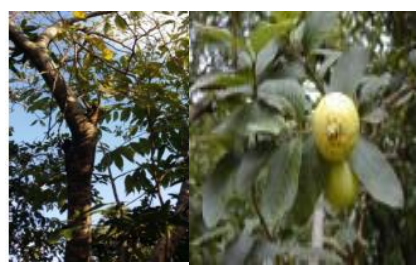

(Lado, 2018)

Akar Kuri Jambu

Lino (Psidium

(nama guajava)

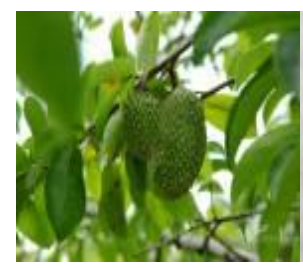

www.biolib.cz/e n/taxon

Biji muricata)

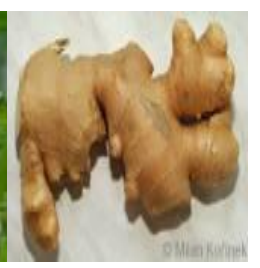

www.biolib.cz/e n/taxon

Jahe (Zingiber officinale)

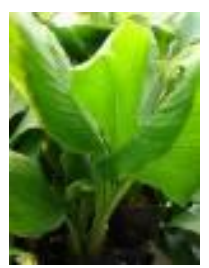

www.biolib.cz/e n/taxon

kunyit putih (Curcuma longa)

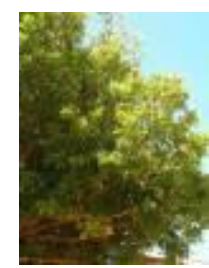

www.biolib.cz/e n/taxon

Mahoni

(Swietenia mahagoni)

belum

ada) 


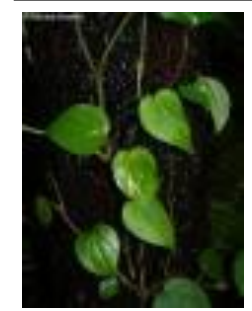

www.biolib.cz/ en/taxon

Sirih (Piper betle)

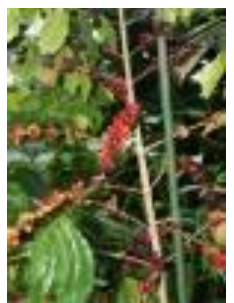

www.biolib.cz/en/taxo $\mathrm{n}$

$$
\text { Kopi (Coffea sp.), }
$$

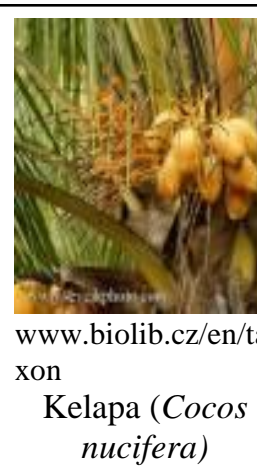
www.biolib.cz/e
n/taxon

$$
\text { Alpukat }
$$
(Persea americana)

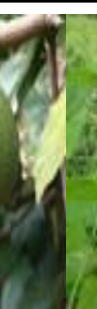

www.biolib.cz/e

Balakacida/bab adotan

(Chromolaena odorata) www.biolib.cz/en/t www.biolib.cz/en/ axon

Karsen

(Muntingia calabura) taxon

Kemangi

(Ocimum basilicum)

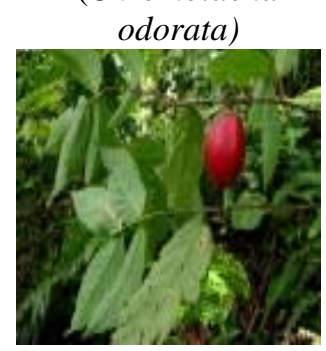

www.biolib.cz/en/taxon

\section{Binahong (Anredera} cordifolia) www.biolib.cz/en/taxon

Mahkota dewa

(Phaleria macrocarpa

Tanaman obat yang digunakan milenial Sumba tentunya pada data tesebut adalah tanaman yang banyak kita temui di seluruh bagian Indonesia. Namun, tentunya jika perilaku ini tidak ditumbuhkan sejak mereka kecil di daerah asal, maka saat mereka berada di daerah trans/ Kota Malang maka perilaku budaya ini akan luntur begitu saja seperti halnya penelitian Andriyani dkk. (13). Hal ini menunjukkan nilai pengetahuan obat dan khasiat obat tradisional melekat pada sebagian generasi milenial Sumba dan ada sebagian kecil yang telah luntur. Tanaman obat tersebut juga merupakan tanaman obat yang paling populer dikonsumsi oleh masyarakat Sumba di daerahnya dari hasil penelitian sebelumnya menyebutkan tanaman sirih, alpukat, kelapa, kumis kucing, ilalang, kunyit, dan pinang. Tanaman tersebut diperoleh dari pekarangan dan juga tanaman lain dari hutan (12).

Perilaku makan sirih pinang juga masih dilakukan meski dalam daerah trans jika mereka menemukan, misalnya ada teman yang pulang kampung atau ada acara daerah di lingkungan tempat tinggal. Menurut generasi milenial Sumba, tradisi makan sirih pinang adalah tradisi yang tidak akan hilang dari diri mereka seperti pada Gambar 3. Sebesar 45\% responden masih makan sirih pinang meski berada di Kota Malang dan 32\% jarang makan sirih karena keberadaanya tidak selalu ada. Namun ada $23 \%$ responden yang sudah tidak makan sirih pinang lagi. Hal ini dapat diprediksi keluarga mereka merupakan keluarga yang modern dan sudah berada jauh dari masyarakat adat.

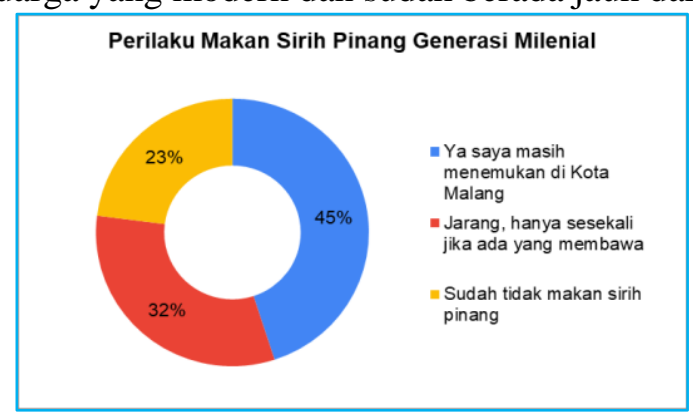

Gambar 3. Persentase perilaku Makan Sirih Pinang oleh Generasi Milenial Sumba 
Konsumsi sirih pinang merupakan salah satu penerapan tanaman/ etnobotani dalam atribut simbolik yaitu tradisi happa atau ma'ma (nginang), yaitu menyuguhkan buah/daun sirih muda (Piper betle L.) dan buah pinang (Arecha cathecu L.) serta kapur sebagai simbol penghormatan dan penerimaan terhadap sesama. Tradisi ini dipraktekan sebagian besar masyarakat di pulau Sumba, dengan intensitas nginang berkisar 8-10 kali/hari (11). Namun, pada penelitian ini belum diketahui frekuensi makan sirih pinang generasi milenial di daerah trans. Hasil wawancara menyatakan mereka mengatakan bahwa tradisi sirih pinang tidak akan hilang, karena ini adalah tradisi Sumba. Aspek keterampilan etnobotani yaitu pada keterampilan mewarnai secara alami benang kain tenun yang merupakan ciri khas wanita Sumba. Salah satu suku di Sumba menyatakan jika wanita yang ingin menikah maka harus mampu menenun kain. Hal ini sebagai seserahan kepada keluarga calon suami dan juga sebagai simbol keluarga.
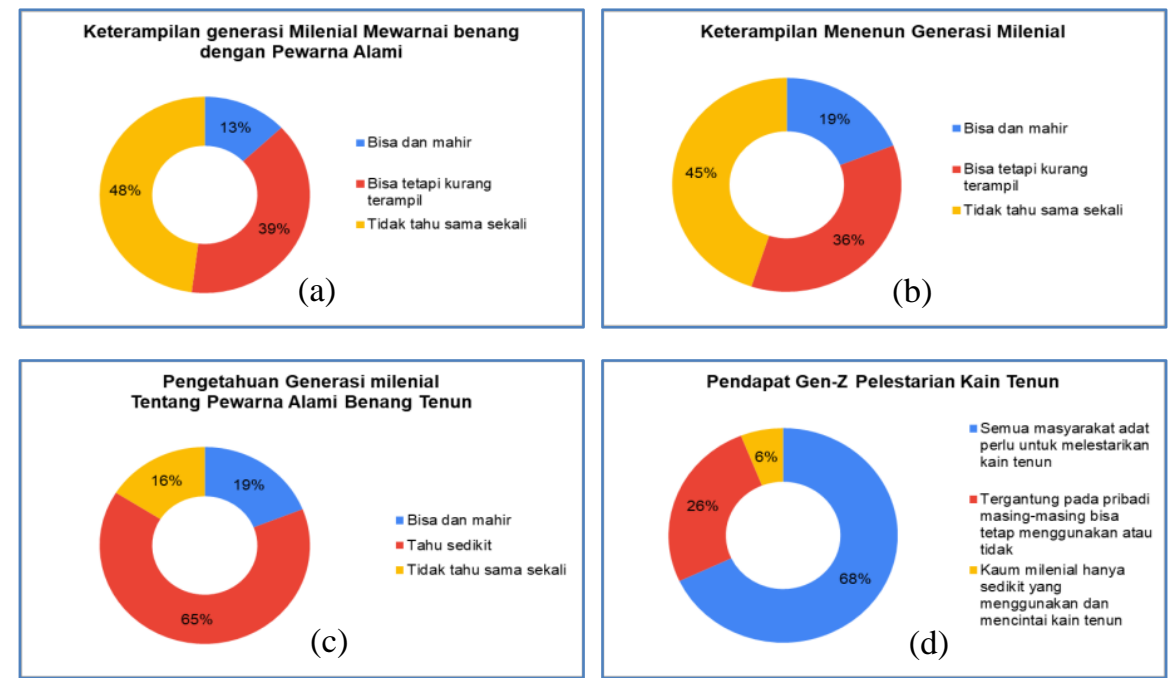

Gambar 4. Persentase Keterampilan dan Pengetahuan Menenun Kain serta Persepsi Kain Tenun oleh Generasi Milenial (Gen-Z) Sumba

Pada Gambar 4. diketahui generasi milenial hanya tinggal sedikit yang mahir dan terampil menenun kain. Pada aspek pengetahuan dan keterampilan menggunakan bahan alam untuk mewarna serta praktik menenun hanya berkisar 13-19\% dari seluruh responden. Hal ini diindikasikan bahwa remaja milenial yang sudah memperoleh pendidikan formal, maka keterampilan menenun tidak dimiliki oleh generasi tersebut. Hasil wawancara responden kunci menyatakan, hanya dirinya yang tidak memiliki keterampilan menenun di keluarganya. Seluruh anggota keluarga baik kakak dan adik dapat menenun dikarenakan saat kecil hingga remaja tetap tinggal bersama orang tua. Sedangkan responden kunci saat kecil sudah sekolah di asrama dan hingga kuliah di Kota Malang tidak banyak berinteraksi dengan orang tua.

Tanaman pewarna yang biasa digunakan hingga saat ini yaitu tanaman Wora/ Nila (Indigofera tinctoria L.) memberi warna hitam dan biru, Kombu/Mengkudu (Morinda citrifolia L.) memberi warna merah, Loba (Symplocos sp.) sebagai penguat warna, Kawalu/Kemiri (Aleurites moluccana L.) sebagai pengikat warna, dan Walakari/Dadap (Erythrina variegata L.) pewarna merah, berdasarkan hasil wawancara responden yang berasal dari Waingapu, Sumba Timur. Hasil wawancara menyatakan di daerah mereka hanya orang tua saja yang memiliki keterampilan mewarnai secara alami, saat ini lebih banyak digunakan benang katun pabrikan yang sudah diwarnai tinggal ditenun. Hal ini dapat disimpulkan bahwa keterampilan menenun generasi milenial telah mengalami penurunan dan tidak diturunkan secara sempurna. Namun, persepsi generasi milenial terhadap kain Sumba masih sangat baik, 68\% responden berpendapat kain ikat Sumba akan tetap lestari dan penting untuk melestarikannya. 


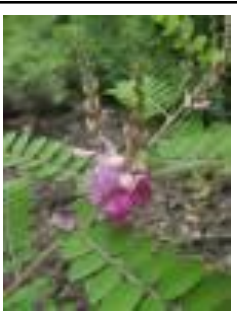

www.biolib.cz/en/ta Xon

Nila (Indigofera tinctoria)

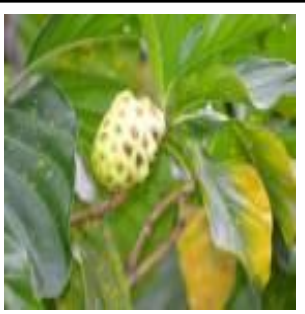

www.biolib.cz/en/ta xon Mengkudu (Morinda citrifolia)

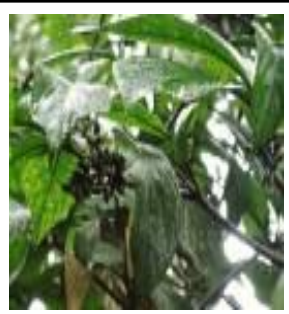

www.biolib.cz/en/ta xon

Tanaman loba (Symplocos sp.)

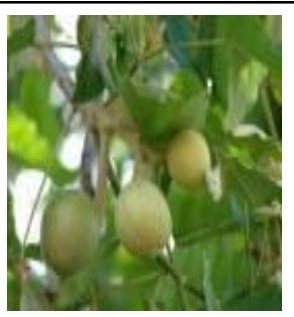

www.biolib.cz/en/ta xon Kemiri (Aleurites moluccanus)

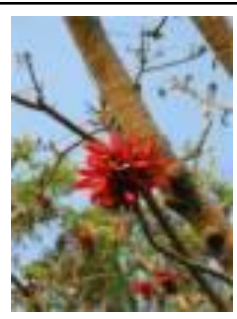

www.biolib.cz/en/ta xon Dadap Merah (Erythrina variegata)

Responden juga diberikan pertanyaan apakah masih memiliki anggota keluarga yang mahir dalam mewarna alami dan menenun, mereka menyatakan masih cukup banyak, data tersaji pada Gambar 5 (a). Sebesar 48\% responden masih berada dalam keluarga yang memiliki keterampilan tenun ikat dengan baik. Meskipun mereka sama sekali tidak tahu teknik menenun, sebesar $45 \%$ responden data pada Gambar 4 (b), serta sebesar 13\% keluarga mereka juga tidak memiliki keterampilan menenun. Keterampilan mewarnai benang secara alami memang sangat jarang ditemukan saat ini, namun generasi milenial masih melakukan kegiatan menenun saat pulang kampung seperti pada Gambar 5 (b). Menurut responden, karena proses pewarnaan alami yang memerlukan waktu lama, serta tidak dimilikinya pengetahuan bahan-bahan alami menyebabkan semakin memudarnya kain ikat tenun yang alami.
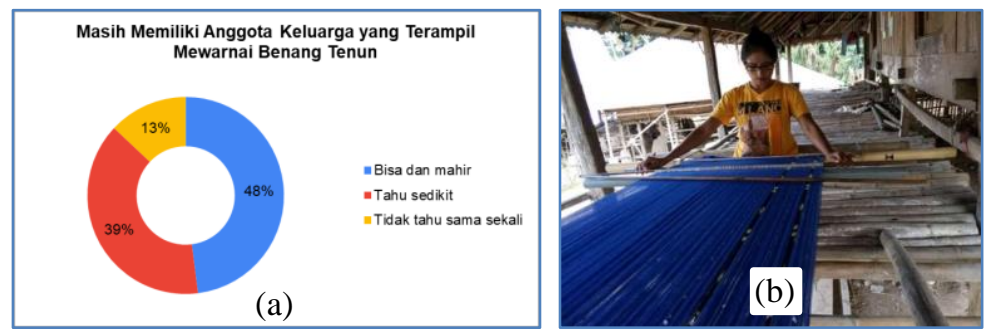

Gambar 5. (a) Persentase anggota keluarga yang mahir Menenun (b) Aktivitas Menenun Generasi Milenial Sumba Saat di daerah.

\section{Diskusi Kajian Sosio-Ekologi Kebudayaan Suku Sumba dan Generasi Milenial Dukungan Sosio-ekologis di Daerah Trans}

Mahasiswa UNITRI berada di Kota Malang dengan komunitas yang berasal dari daerahnya. Sebagian besar anak daerah yang menempuh kuliah di kota besar memiliki kelompok organisasi daerah yang telah mendahuluinya di kota tersebut. Dari hasil penelitian menyatakan culture shock atau kesenjangan budaya yang berbeda dari daerah asal dan daerah tujuan juga dialami oleh mahasiswa di UNITRI [11]. Namun, dengan adanya teman dari daerah yang sama mereka sebagai anak rantau merasakan kenyamanan dan betah untuk berada di daerah tujuan karena masih merasakan kebudayaan daerah asalnya. UNITRI sebagai kampus dengan sebagian besar mahasiswa daerah dari sebagian besar wilayah di Indonesia menyediakan iklim ekologis yang baik untuk mengenal budaya satu sama lain. Kegiatan rutin yang diadakan dalam rangka mewadahi unjuk kebudayaan yaitu dengan kegiatan pentas seni pada peringatan kesaktian Pancasila dan juga hari Kemerdekaan Republik Indonesia. Hal ini merupakan kondisi sosiologis yang mendukung generasi milenial Sumba untuk dapat melestarikan kebudayaannya meskipun berada di daerah perantauan sementara/trans.

Pada tradisi makan sirih pinang, generasi milenial Sumba tetap melestarikan tradisi tersebut jika menemukan sirih dan pinang yang dibawa oleh saudara atau teman yang membawanya dari 
e-Jurnal Ilmiah BIOSAINTROPIS (BIOSCIENCE-TROPIC)

Volume : 7/ No : 1 / Halaman 63 - 73 / Agustus Tahun 2021

ISSN : 2460-9455 (e) - 2338-2805(p)

kampung atau mereka mencari sendiri sirih dan pinang lalu dikonsumsi pada acara budaya di asrama mereka. Tradisi menggunakan kain adat juga masih dilestarikan di daerah perantauan yaitu pada saat hari bear dan hari peringatan nasional. Mereka juga saling menjual kain adat pada teman atau saudara yang memerlukan meskipun dalam hanya sedikit. Namun, dari aspek penggunaan tanaman obat, mereka masih sangat mahir dan terbiasa untuk menggunakannya dalam mengobati penyakit ringan. Bahkan jika ada mahasiswa yang sakit berat di daerah trans, maka mereka akan berusaha untuk pulang kampung dan mencari pengobatan tradisional. Hal ini masih dilakukan oleh sebagian besar generasi milenial Sumba.

\section{Kearifan Lokal, Kepercayaan Marapu dan Modernisasi Budaya}

Hasil penelitian ini menunjukkan bahwa nilai sebagai aspek tertinggi dari tingkat pengetahuan perilaku manusia telah dimiliki oleh generasi milenial. Nilai-nilai kebudayaan ini masih ada terlihat dari perilaku mengkonsumsi obat tradisional, masih makan sirih pinang meskipun berada di daerah trans namun dengan frekuensi yang lebih sedikit, serta berpendapat bahwa kain tenun Sumba merupakan identitas mereka. Melalui analisis tingkat nilai/ human value maka dapat menjadi implikasi bahwa dengan pengukuran salah satu aspek saja misalnya dengan melihat perilaku tanpa melihat penilaian/persepsi responden, maka kita tidak dapat melihat secara utuh sistem nilai yang terjadi. Melalui penelitian sosio-ekologi meskipun dalam keterbatasan, diharapkan menjadi pendekatan baru dalam mengkaji sistem interaksi manusia dengan ekologi atau lingkungannya. Selain itu sangat dimungkinkan penelitian lintas bidang untuk mampu melihat suatu hal dari berbagai aspek secara menyeluruh (1).

Kearifan lokal oleh generasi milenial Sumba masih belum dapat diprediksi untuk masa yang akan datang. Hal ini diperkirakan semakin pesatnya jumlah penduduk dan meningkatkan angkatan kerja, serta menurunya jumlah lahan pertanian dan tempat tinggal juga akan mendesak perubahan gaya hidup generasi milenial saat kembali ke daerah asal. Hasil wawancara menunjukkan keluarga yang memiliki kepercayaan Marappu masih kental dengan alam dalam berbagai aspek kehidupannya. Seperti larangan-larangan yang masih mereka laksanakan, baik larangan dalam menggunakan hutan tanpa aturan adat. Dengan demikian, kepercayaan marappu sangat penting dalam pelestarian kearifan lokal. Hal ini juga senada dengan penelitian sebelumnya (15). Namun menurut penelitian tersebut dan juga hasil wawancara kami menunjukkan generasi milenial sangat kecil untuk menjadi penerus marapu atau pemuka adat. Bahkan orang tua mereka merasakan sudah tidak ada lagi karunia dari leluhur/nenek moyang untuk adat mereka. Penelitian sebelumnya menunjukkan adanya penurunan jumlah penganut kepercayaan ini dikarenakan modernisasi dan masuknya agama nasional yang meningkat pesat sampai tahun 1990-an (6) (15).

Berbagai dinamika sosial juga terjadi di daerah dengan suku adat dan akuisisi pemerintah. Namun, dengan semakin banyaknya generasi penerus yang berpendidikan diharapkan memiliki efek positif terhadap keberadaan budaya dan kelestarian alam lingkungan asalnya. Data menunjukkan bahwa sebagian besar generasi milenial memiliki persepsi positif terhadap budayanya dan nilai luhur kearifan lokal yang dipegang masih tetap ada. Namun, seiring majunya perkembangan dunia dan modernisasi budaya lain juga mempengaruhi budaya setempat. Salah satu contohnya keterampilan tenun ikat yang sangat jarang dimiliki oleh generasi penerus, dimungkinkan akan hilang dan menjadi sejarah. Hal ini merupakan kelemahan yang dimiliki suku Sumba. Namun demikian, generasi milenial mampu melihat peluang dalam perspektif lainnya yaitu kegiatan pemasaran produk kain tenun ke mancanegara melalui modifikasi produk lainnya. Mereka menghargai kain ikat Sumba sebagai warisan dari orang tua kepada anaknya serta sebagai warisan budaya yang harus menjadi identitas diri mereka.

Modernisasi budaya semakin lama menjadi ancaman kelestarian budaya setempat. Kelemahan yang dimiliki dari kondisi sosio-ekologis Sumba yaitu semakin meluasnya akuisisi pemerintah atas lahan dan juga investor asing dimana mengurangi satu masalah namun juga menimbulkan masalah lainnya. Kajian kearifan lokal dan kekayaan alam Sumba masih banyak diperlukan dan juga 
penguatan nilai-nilai budaya pada kegiatan pendidikan dan keagaman saling bersinergi melihat titik tengah menuju kelestarian alam dan masyarakat adat. Melalui pendekatan kajian sosio-ekologis maka dapat menjadi suatu pandangan menyeluruh/holistik. Kajian sistem sosio-ekologis merupakan faktor multi dimensi secara parametrik dapat dikaji dan didalami (11). Kajian etnobotani dalam penelitian ini masih sebagian kecil dari aspek nilai-nilai yang terkandung dalam kebudayaan Suku Sumba. Melalui pendekatan sosio-ekologis dapat dinilai seberapa besar ketergantungan dan hubungan manusia dengan lingkungan alamnya, bagaimana manusia memberikan penilaian sumber daya alam terhadap kebutuhan biologisnya, serta bagaimana hubungan alam dengan pemikiran manusia, tubuh manusia, serta jiwa manusia. Namun, pada penelitian ini masih belum bisa menjawab pertanyaan tersebut secara detil dan diharapkan selanjutnya dapat dijabarkan lebih menyeluruh(15) . Kajian sosio-ekologis ini diharapkan akan membuka perspektif baru pemerintah untuk melihat suatu budaya dan alam agar tetap lestari melalui pendekatan yang lebih holistik dan mengenali jati dirinya, bukan kebarat-barat-an ataupun mengikuti arus budaya luar yang semakin mengancam kebudayaan asli dan lingkungan alam.

\section{Kesimpulan}

Penelitian ini menunjukkan bahwa sebagian besar (45-48 \%) generasi milenial Sumba masih memegang nilai-nilai adat dalam kehidupan sehari-hari meskipun berada di kota trans sementara. Generasi milenial Sumba memiliki keterampilan dalam meracik dan mengkonsumsi obat tradisional dari beberapa tanaman yang mudah ditemui di sekitar mereka, akar kayu/Linno, daun Jambu Biji (Psidium guajava), daun sirsak (Annona muricata), jahe (Zingiber officinale), kunyit putih (Curcuma zedoaria), daun dan akar mahoni (Swietenia mahagoni), daun sirih (Piper betle), minyak kelapa (Cocos nucifera), alpukat (Persea americana), daun balakacida/babadotan (Chromolaena odorata), buah karsen (Muntingia calabura), akar kemangi (Ocimum basilicum), daun kopi (Coffea sp.), daun binahong (Anredera cordifolia), dan buah mahkota dewa (Phaleria macrocarpa). Sebagian dari mereka $48 \%$ masih memiliki keterampilan menenun sebagai kewajiban wanita Sumba, namun sebagian lagi $13 \%$ tidak mampu menenun, tetapi masih memiliki keluarga dengan keterampilan menenun. Persepsi generasi milenial sangat baik $48 \%$ dalam melestarikan kain adat mereka"tenun ikat". Meskipun dengan harga yang mahal mereka meyakini bahwa kain tenun ikat adalah kain yang sangat berharga dan memiliki nilai sejarah keluarga yaitu sebagai pemberian orang tua dengan membuatkan kain untuk anak-anaknya. Namun demikian, ada beberapa ancaman yaitu proses pewarisan pengetahuan dan keterampilan yang tidak berjalan dengan baik pada generasi milenial yang mengenyam pendidikan. Mereka sudah tidak memiliki waktu banyak untuk berinteraksi dengan keluarga. Serta ancaman modernisasi kebudayaan sehingga kebudayaan asli seperti kepercayaan Marappu sulit untuk mendapatkan penerusnya.

Saran untuk penelitian selanjutnya yaitu perlu meningkatkan kuantifikasi faktor-faktor yang tersebut pada penelitian ini menjadi sebuah model untuk pendekatan sosio-ekologis dalam kajian etnobotani serta kajian lainnya untuk konservasi lingkungan berbasis masyarakat lokal. Tahapan selanjutnya diperlukan kajian sosio-ekologi meliputi kajian tantangan kehidupan masa depan, tantangan kelangkaan sumber daya alam, serta tantangan nilai budaya, apakah mampu bertahan pada generasi selanjutnya.

\section{Ucapan Terima Kasih}

Kepada responden yaitu mahasiswa kami di UNITRI kami sampaikan terima kasih atas kerjasama dan bantuan saudara sekalian. Data yang diberikan sangat membantu dalam kajian penelitian ini meskipun dalam kondisi pandemik Covid-19. Tanpa bantuan saudara sekalian maka tidak ada data penelitian yang dapat kami analisis. Terima kasih kepada kampus UNITRI dan sejawat kami telah menyediakan ruang dan waktu sebagai bahan penelitian kami. 


\section{Daftar Pustaka}

1. Vell Jacqueline S. Strategic Framing of Adat in Land-Acquisition Politics in East Sumba. Asia Pacific J Anthropol. 2019;20(5):435-52.

2. Adams RL. The megalithic tradition of West Sumba, Indonesia: An ethnoarchaeological investigation of megalith construction. Diss Abstr Int Sect A Humanit Soc Sci [Internet]. 2008;69(4-A):1415. Available from: http://ezproxy.library.uvic.ca/login?url=http://search.ebscohost.com/login.aspx?direct= true \&db=psyh\&AN=2008-99190-559\&site=ehost-live\&scope=site

3. Obie M, Soetarto E, Sumarti T, Saharuddin S. Konflik Etnis Di Pesisir Teluk Tomini: Tinjauan Sosio-Ekologi Politik. Al-Tahrir J Pemikir Islam. 2014;14(2):319.

4. Charles A. People, oceans and scale: Governance, livelihoods and climate change adaptation in marine social-ecological systems. Curr Opin Environ Sustain [Internet]. 2012;4(3):351-7. Available from: http://dx.doi.org/10.1016/j.cosust.2012.05.011

5. Astri Lestari A, Hadi Dharmawan A. Dampak Sosio-Ekonomis Dan Sosio-Ekologis Konversi Lahan. Sodality J Sosiol Pedesaan. 2011;5(1):1-12.

6. Jones NA, Shaw S, Ross H, Witt K, Pinner B. The study of human values in understanding and managing social-ecological. 2019;21(1).

7. Soeriadiredja P. Marapu: Konstruksi Identitas Budaya Orang Sumba, NTT. J Antropol Indones. 2013;34(1).

8. Julung H, Ege B. Etnobotany in Customary Ceremony in Dayak Society , UUD Danum. 2020;(09):429-40.

9. Ramadhan SF, Metusala D, Sinaga MO. Potensi Pengembangan Tradisi Etnobotani Sebagai Ekowisata Berkelanjutan: Studi Kasus Suku Mentawai di Pulau Siberut, Kepulauan Mentawai. J Pro-life. 2017;4(2):364-74.

10. Ledi F, Kusmanto B, Agustito D. Identifikasi Etnomatematika pada Motif Kain Tenun Sumba Barat. UNION J Ilm Pendidik Mat. 2020;8(1):87.

11. Njurumana GN. Village Community and Flora Biodiversity Management in Home Garden System At Central of Sumba Regency. J Penelit Kehutan Wallacea. 2016;5(1):25.

12. Purwanti E, Mulyatin T. Ethnobotany Medicinal Plants For Local Community in Southwest Sumba District. 2018;231(Amca):544-7.

13. Jadid N, Kurniawan E, Himayani CES, Andriyani, Prasetyowati I, Purwani KI, et al. An ethnobotanical study of medicinal plants used by the Tengger tribe in Ngadisari village, Indonesia. Vol. 15, PLoS ONE. 2020.

14. Mitasari Z, Istikomayanti Y. Studi pola penyesuaian diri mahasiswa luar Jawa di Universitas Tribhuwana Tunggadewi Malang. Semin Nas dan Gelar Prod. 2017;(0341):796-803.

15. Riti SB. Bara Marapu sebagai Kepercayaan Asli Orang Sumba: Perspektif Pelayanan Hak Sipil dan Ancaman Kepunahan ). Harmoni [Internet]. 2015;14(1):120-37. Available from: file:///D:/Data/S2/Semester 3/Proposal/Materi/agama marapu terancam punah dan perekonomian/httpdocplayer.info30011145-Bara-merapu-sebagaikepercayaan-asli-orang-sumba-perspektif-pelayanan-hak-sipil-dan-ancamankepunahan.html.pdf 